\title{
AÜS
}

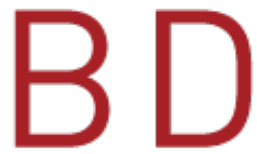

Anadolu Üniversitesi Sosyal Bilimler Dergisi

Anadolu University Journal of Social Sciences

\section{The Covid-19 Crisis: Opportunity or Threat for Populist Radical Right Parties in Europe? ${ }^{1}$}

\author{
Sevgi ÇiLINGiR ${ }^{2}$
}

Submitted by: 06.04 .2021

Accepted by: 13.09 .2021

Article Type: Research Article

\begin{abstract}
Starting as a public health problem, the Covid-19 pandemic has become a multi-dimensional crisis that involves various policy areas. Crises have the potential to change priorities and trigger various reflexes in any given society, including a realignment on the political spectrum. In Europe, Populist Radical Right Parties (PRRPs) were on the rise due to the previous crises in Europe. In this context, have these parties appealed more or less to voters during the pandemic? This study aims to investigate the impact of the Covid-19 pandemic on the discourse and popular support of European PRRPs in its first year. The responses of the PRRPs of Austria, France, Germany and Italy to the pandemic and its governance are explored through leaders' Twitter posts. Changes in popular support for the political mainstream and the PRRPs are examined through recent opinion polls. The trend of the rise of European PRRPs before the pandemic is revisited and discussed in light of the findings.
\end{abstract}

Keywords: Covid-19, Crisis, Europe, Populist Radical Right, Popular Support

Atıf: Çilingir, S. (2021). The Covid-19 crisis: Opportunity or threat for populist radical right parties in Europe?. Anadolu Üniversitesi Sosyal Bilimler Dergisi, 21(3), 805-826.

\footnotetext{
${ }^{1}$ Due to the use of public resources, informed consent or ethics committee approval was not required.

${ }^{2}$ Dokuz Eylül University Faculty of Business Department of International Relations, sevgi.cilingir@deu.edu.tr, ORCID: 0000-0003-4597-6691
} 


\section{AÜS}

\section{için Fırsat mı, Tehdit mi? \\ Covid-19 Krizi: Avrupa'daki Popülist Radikal Sağ Partiler} Sevgi ÇiLiNGiR ${ }^{3}$

\section{Öz}

Bir halk sağlığı sorunu olarak başlayan Covid-19 pandemisi, çeşitli politika alanlarını etkileyen çok boyutlu bir krize dönüşmüşü̈r. Krizler, siyasi skalada yeniden konumlanma dâhil olmak üzere, her toplumda öncelikleri değiştirme ve çeşitli refleksleri tetikleme potansiyeli taşır. Avrupa'da Popülist Radikal Sağ Partiler (PRSPler), geçmiş krizler üzerine yükselişe geçmiştir. Bu bağlamda, pandemi döneminde bu partiler seçmenlere daha mı fazla, yoksa daha mi az hitap etmiştir? Bu çalıșma, Covid-19 pandemisinin, ilk yllında, Avrupa PRSPlerinin söylem ve popüler desteğine etkisini incelemeyi amaçlamaktadır. Avusturya, Fransa, Almanya ve İtalya PRSPlerinin pandemi ve yönetimine tepkileri, liderlerinin Twitter iletileri üzerinden araştırılmaktadır. Gerek ana akıma, gerekse PRSPlere popüler destekteki değişimler, yakın dönemli kamuoyu yoklamaları üzerinden incelenmektedir. Avrupa PRSPlerinin pandemi öncesindeki yükseliş eğilimi, bulgular ışı̆̆ında irdelenmekte ve tartışılmaktadır.

Anahtar Kelimeler: Covid-19, Kriz, Avrupa, Popülist Radikal Să̆, Popüler Destek

\footnotetext{
${ }^{3}$ Dokuz Eylül Üniversitesi İşletme Fakültesi Uluslararası İlişkiler Bölümü, sevgi.cilingir@deu.edu.tr, ORCID: 0000-0003-4597-6691
} 


\section{Introduction}

With their anti-establishment discourse, fueling public concerns about European integration and immigration, Populist Radical Right Parties (PRRPs) were on the rise in Europe before the pandemic. Their ascent had become apparent at the European Union (EU) level, as well as the national level (European Parliament, 2021). PRRPs pose a threat to European integration, already under stress since the 2008-2009 financial crisis and 2015 refugee crisis. More important, although their ideologies had approached the political mainstream, PRRPs challenge the principles and values of pluralistic democracies (Aknur \& Saylan, 2020, pp. 297-300).

The Covid-19 pandemic has become a multi-dimensional crisis that involves policy areas such as public finance, internal security and international relations. By disrupting the status quo, crises may cause changes in a political system. For instance, security crises may constitute, amplify or transform the form of nationalism in a country (Woods, et.al., 2020, p. 819). With its urgency and magnitude, the pandemic has already changed policy priorities in all countries, where resources are dedicated to health and social security. It also has the potential to trigger a realignment in the political spectrum. Crises were proven to be exaggerated by and facilitate the electoral performance of PRRPs in Europe before the pandemic (Albertazzi \& McDonnell, 2008; Mudde \& Rovira Kaltwasser, 2017). New studies are needed to find out how these parties have reacted to the current crisis and the implications on their rise.

This study approaches the Covid-19 pandemic as a major crisis and seeks to explore its relationship with European PRRPs' discourse and performance, during its first year. How did PRRPs frame Covid-19 and the policies adopted by governments to mitigate its effects? Did they continue with or alter their former arguments? More important, have they gained or lost potential voters? In other words, is the pandemic an opportunity or threat for their performance in the coming elections?

The study examines these issues with a comparative methodology. Four cases were selected, in which PRRPs had founded their propaganda upon similar themes and increased their popular support in the past decade: Austria, France, Germany and Italy. By inquiring similarities and differences in their reactions and popular support during the pandemic, the study seeks to find out whether a common trend may be inferred.

The study begins by demonstrating the context for European PRRPs before the pandemic. First, main elements of their discourse and the factors which had contributed to their rise are determined in light of the findings of the previous literature. After the explanation of the methodology, political alignment, government composition and PRRPs' relative position in each country prior to the Covid-19 outbreak are delineated. Following the presentation of main issues related to the pandemic and its governance, the study explores the discourse of the PRRPs. After establishing the progression, main themes and omissions in the parties' discourses, developments in the popular support for PRRPs are inquired in comparison with the political mainstream - major government and opposition parties. The findings are discussed by revisiting the literature, in order to determine the possibilities for the future.

\section{PRRPs in Europe Before the Pandemic: Discourse, Popular Support and Crises}

PRRPs are defined by a combination of populism and radical right ideology. They differ from the extreme right, with respect to their attitude towards democracy. Although they are opposed to some elements of liberal democracy, they mobilize within democracies and do not advocate authoritarian regimes (Öner 2014, p. 86). However, social authoritarianism is a common feature of PRRPs in Europe, manifest in their prioritization of public order (Mudde \& Rovira Kaltwasser 2017, p. 34). Moreover, under the disguise of direct democracy, they seek to undermine constitutional guarantees against unlimited majoritarian rule. By founding their discourse upon a "politics of opposition" that is politically divisive and culturally exclusivist, they pose a threat to social cohesion and democratic institutions (Aknur \& Saylan, 2020, pp. 297-300). 
Lacking a sound ideological basis, the defining characteristic of PRRPs is the discursive construction of a binary opposition between the people and the elite (Mudde \& Rovira Kaltwasser, 2017, pp. 5-7). Their antiestablishment rhetoric, claiming to defend the interests of "ordinary people" - a rather "elusive characterization of their target constituency," may appeal to different segments of society at different times, who feel left out by mainstream politics (van Kessel, 2015, p. 12). Their political capital is based on charismatic leadership rather than organizational strength. Leaders connect directly with this imagined "people", constructed in a homogenizing manner (Albertazzi \& McDonnell, 2008, pp. 5-6; van Kessel, 2015, pp. 14-15). In order to nourish this connection, party leaders use the media, especially social media, extensively. This aspect has factored in the characterization of PRRP populism as a political strategy, rather than an ideology (Weyland, 2017). They homogenize the mainstream into a single "other", by portraying multiple actors - political parties, the media, intellectuals and the bureaucracy - as a single category of corrupt elite who further their own agenda rather than the well-being of the people (Mudde \& Rovira Kaltwasser 2017, pp. 10-11). They argue that political decisions should be made on the basis of "common sense", a simplified version of the general will, as opposed to the interests of this elite (Mudde, 2017).

PRRPs' approach to collective identity is based on nativism, which excludes people and cultures they construct as foreign. Typically raised against immigrants, this discourse may also exclude ethnic and religious minorities (van Kessel, 2015, pp. 24-25). Although they target similar groups, PRRPs' attitude towards immigrants and minorities differs from the extreme right. They define the people in terms of the nation-state, but they do not necessarily define the nation on ethnic or racial terms (Mudde \& Rovira Kaltwasser, 2017, p. 10). Whereas the extreme right seeks the purification of the nation on the basis of racial or ethnic superiority, PRRPs' argument is centered upon purification on a cultural basis. This rejection of pluralism may escalate to a form of cultural racism (Aknur \& Saylan, 2020, p. 299).

Another common theme found in European PRRPs' discourse, capitalizes upon economic hardship and resonates with the lower socioeconomic strata of European societies, especially since the financial crisis of 2008-2009 and the following sovereign debt crisis. Although PRRPs do not originate from the left, they usually advocate economic protectionism in their attempt to appeal to their anti-globalist electoral base (Verbeek \& Zaslove, 2017). In line with their nativism and anti-immigrant attitudes, they also advocate welfare chauvinism (van Kessel, 2015, pp. 25-26).

PRRPs' anti-elitism, ethno-cultural and economic nativism are combined in an accentuated Euroscepticism. They oppose either EU membership (hard Euroscepticism), or EU integration in some policy areas (soft Euroscepticism), on the basis of sovereignty. In this narrative, the EU is dominated by the EU elite, who are disengaged from the people and as corrupt as the national elite (van Kessel, 2015, p. 27). This opposition to the polity aspect as well as policy aspect of the EU differentiates their discourse from other Eurosceptics (Vasipoulou, 2011, pp. 225-226). Nonetheless, all PRRPs concur with the idea of Europe as the embodiment of civilization, and include Christianity in its definition. They all reject political integration, yet most are in favor of continued cooperation between EU members (Vasipoulou, 2011, p. 234). Their economic arguments against the EU reflect their protectionism and welfare chauvinism, which has become more pronounced since the financial crisis. In this case, the EU is portrayed as a corrupt structure, which, with the help of the national pro-EU elite, siphons off the nations' resources and redistributes them at the expense of the people (Mudde \& Rovira Kaltwasser, 2017, pp. 34-35). Migration has been another theme in PRRP Euroscepticism, especially since the 2015 refugee crisis. Western European PRRPs also object to intra-EU migration. For example, free movement, a central theme in United Kingdom Independence Party's (UKIP) leave campaign, was a major factor in Brexit referendum results (Tournier-Sol, 2020). 
In the past decade, PRRPs have generally increased their electoral performance in Europe. Supply side explanations for this phenomenon focused on the internal characteristics of the parties - such as leadership and program, performance of other political parties, and opportunity structures provided by the political and institutional system (Mudde \& Rovira Kaltwasser, 2017, pp. 97-108; van Kessel, 2015, pp. 17-28). Demandbased approaches inquired the characteristics of their electoral base in order to reveal how PRRPs' arguments appealed to different categories of voters. Overall, PRRPs had mostly gained votes from socioeconomic groups that were disadvantaged by globalization and Europeanization; disillusioned by the capacity of the political mainstream to channel their interests. With their anti-immigration attitude, Euroscepticism, economic and cultural nativism, PRRPs had appealed to their grievances with the status quo (Mudde \& Rovira Kaltwasser, 2017, pp. 102-103; van Kessel, 2015, pp. 24-27).

Economic and political crises benefit PRRPs, because a crisis situation reduces the ability of the political mainstream, to which these parties stand against, to provide quick solutions. This mitigation gap enables PRRPs to offer themselves as a serious alternative. Therefore, PRRPs focus on exaggerating crises and keeping them on the political agenda (Albertazzi \& McDonnell, 2008, pp. 5-6). Accordingly, the increase in European PRRPs' electoral performance at the national and EU levels is explained as a result of the 2008-2009 financial crisis and its long term repercussions on the national economies of member states (Kriesi \& Pappas, 2015; Poli, 2016). Fueled by the framing of the media of asylum as an urgent threat to economies and societies, PRRPs have also gained electoral support through the European refugee crisis of 2015 (Ellinas, 2018, pp. 391-392; Mudde \& Rovira Kaltwasser, 2017, p. 106).

\section{Methodology}

The study adopts a comparative, qualitative methodology. Austria, France, Germany and Italy were selected to inquire developments regarding European PRRPs during the pandemic. Although the countries constitute different electoral and political systems, all four governments adopted similar measures around the same periods. The PRRPs have had different ideological backgrounds and levels of popular support before the pandemic. However, their discourses were focused on similar issues and their votes had increased in the previous decade (Vasipoulou, 2011; van Kessel, 2015; Mudde \& Rovira Kaltwasser, 2017). Furthermore, they were all in opposition during the period under study in a position to challenge government policies. These facilitate comparisons specific to PRRPs.

PRRPs' reactions and popular support during the pandemic were inquired for the first year of the pandemic, beginning with the announcement of Covid-19 by World Health Organization (WHO) as an international health emergency (from January 30, 2020 to January 31, 2021). During this period, the countries faced the first wave of the outbreak, a receding period and a second wave, accompanied by various policy responses and public reactions, enabling the detection of changes for the PRRPs.

PRRPs are characteristically leadership parties and their propaganda relies heavily upon leaders' direct communication with the electorate. Hence, PRRP leaders are active users of social media which provide opportunity for frequent public engagement (van Kessel, 2015, pp. 14-15; Weyland, 2017). This is much more important at a time of limitations on public gatherings, lockdowns and curfews. Accordingly, the study uncovered PRRPs' discourse through party leaders' Twitter posts. Their Tweets were scanned for signifiers (hashtags and words) related to the pandemic (Covid-19 and related terms, pandemic, health, crisis). The selected posts were examined for commonalities and differences on the issues regarding the pandemic and its governance. The leaders' Twitter accounts were public official accounts which did not require user approval for following. Therefore, informed consent or ethics committee approval was not required. 
The study sought to find out changes in popular support at the national level. In the period under study, there were no general or presidential elections. Despite delays due to lockdown orders, some regional and local elections were held in the four countries, as well as two referenda in Italy and France. ${ }^{4}$ However, depending on the region and issue, the results may vary greatly from national elections. Therefore, instead of data from the elections, voting intentions for national or presidential elections that were derived from public opinion survey results were used. Presented at intervals within the year, the changes in popular support for the PRRPs were compared with the changes for government and other major opposition parties, in order to detect emerging trends.

\section{Political Alignment and Government Composition Towards the Pandemic}

All of the PRRPs were in opposition during the first year of the pandemic. However, some had taken part in coalition governments (Austria, Italy) or had become a significant competitor for presidency (France) before. PRRPs performed even better at the EU level. In in 2019 EP elections, they became the first parties in Italy and France (European Parliament, 2021). The composition of governments and the relative position of the PRRPs towards the pandemic are explained below.

\section{Austria}

In Austria, the leading PRRP is Freedom Party of Austria (FPÖ). It was founded in 1956 by former members of the Nazi Party. With the slogan "Austria first”, FPÖ has advocated national supremacy against immigration and EU membership. It became the coalition partner of the conservative People's Party (ÖVP) in the early 2000s, triggering sanctions to the country by other EU members. With the rise of right wing populism in Europe in the 2010s, FPÖ's votes increased, leading to a second coalition with ÖVP (Aknur \& Saylan, 2020, pp. 301-305).

The 2013 general election signaled a realignment of voters in Austria. Mainstream political parties - ÖVP and Social Democratic Party (SPÖ) - lost considerable votes. Both FPÖ and Greens gained a record number of seats and some fringe parties managed to pass the electoral threshold. This trend continued in the 2017 election. FPÖ became third (26\%), following ÖVP (36\%) and SPÖ (26.9\%) (Bodlos and Plescia, 2018). FPÖ has also been the third party in EP elections since 2014 (European Parliament, 2021).

Following the 2017 general election, ÖVP formed a coalition government with FPÖ. In 2019, the government dissolved because of the Ibiza corruption scandal involving the FPÖ leader, followed by a snap election. Although ÖVP became first (38\%) and the ranking of the major parties remained the same, FPÖ lost its former support (16\%) as well as its leader who had resigned in response to the scandal ("Austria Election," 2019)5. Austria has been governed by ÖVP - Greens (14\%) coalition during the pandemic.

\section{France}

Formerly named as National Front (FN), ${ }^{6}$ National Rally (RN) is the leading PRRP in France. Established in 1972, it became a populist party, moderating its far right ideology and adopting anti-elitism, nativism and Euroscepticism (Mudde \& Rovira Kaltwasser, 2017, pp. 34-35). It became an established party in French politics in the 2010s, under the leadership of Marine Le Pen (Mudde \& Rovira Kaltwasser, 2017, pp. 53-54). It became the first party in 2014 and 2019 EP elections (European Parliament, 2021). Le Pen, who was third in the first round of 2012 presidential elections, became second in 2017 presidential elections. She competed in

\footnotetext{
4 In France, a referendum was held on October 4, 2020, for the independence of New Caledonia, which was rejected (53\%). In Italy, the constitutional referendum (September 20-21, 2020) resulted in the decision to reduce the number of seats in both houses of the legislature (70\%).

5 FPÖ was led by Hofer during the period under study. In June 2021, leadership passed on to Kickl, who is more radical ("Austria: Herbert Kickl," 2021).

6 The party changed its name in 2018 .
} 
the second round against Emmanuel Macron, the leader of liberal centrist The Republic Forward! (LREM). Although she lost the second round (33.9\%), she competed very closely with Macron in the first round (2421.3\%). In the second round of 2017 legislative elections (lower house), LREM became the first party (43.1\%), followed by conservative The Republicans (LR) (22\%), RN (8.8\%) and centrist Democratic Movement (MoDem) (6\%). Although RN was third in terms of votes, it became eighth in terms of parliament seats (Alvarez-Rivera, 2019).

Since 2017, governments have been dominated by LREM, but also included members from MoDem and various leftist and center right parties. The initial Philippe government was dissolved within a few months due to ministerial resignations upon fraud allegations involving MoDem (“Top Macron Ally," 2017). France was governed by Second Philippe government (June 2017-June 2020) during the initial phase of the pandemic. Castex became Prime Minister in July 2020 reshuffle, in response to the economic crisis that accompanied the pandemic. The current government includes ministers from other political parties and independents as well as LREM, MoDem, MR, Agir and TDP (Henley, 2020). RN is the second party in opposition, after conservatives (LR).

\section{Germany}

Since 2005, under Chancellor Angela Merkel, conservatives have dominated Germany's political field. The country has been governed by grand coalitions of conservatives and social democrats. The only exception was the 2009-2013 period, when conservatives formed a coalition with liberal Free Democratic Party (FDP) instead. The alliance of Christian democrats - Christian Democratic Union (CDU) and Christian Social Union of Bavaria (CSU) - has been the first in general elections since 2005, with 32.8-41.5\% of the votes, followed by Social Democratic Party of Germany (SPD) with $20.5-34 \%$ of the votes (Alvarez-Rivera, 2019) ${ }^{7}$.

The leading PRRP in Germany is Alternative for Germany (AfD). It was founded in 2013 as a Eurosceptic center right party, mainly by CDU dissidents. Since 2015, in response to Merkel's open asylum policy, it has embraced an anti-immigration attitude that borders on racism, which pressured CDU to a stricter position on immigration (Aknur \& Saylan, 2020, pp. 306-307). The party is divided between moderates and far right extremists. ${ }^{8}$ Most of its electoral support is from Eastern Germany (“AfD," 2019). AfD was not represented in the federal parliament (Bundestag) before 2017, due to the electoral threshold. In the2017 national election, AfD became third (12.6\%), after CDU/CSU (32.9\%) and SPD (20.5\%), surpassing FDP (10.7\%). First time in parliament, AfD gained 94 seats, becoming the strongest party of the opposition (Alvarez-Rivera, 2019). By 2018, it was represented in all of the state parliaments as well (Aknur \& Saylan, 2020, p. 305). AfD ranked lower in EP elections. Nevertheless, it has been on the rise. It became fifth in 2014 and fourth in 2019 (European Parliament, 2021).

\section{Italy}

There are two successful populist anti-establishment parties in Italy. Founded as a regional federalist party in 1991, The League (Lega), formerly named as The Northern League (LN), ${ }^{9}$ originated in an ethno-nationalist, radical right ideology. Since 2013, it has been led by Matteo Salvini, who abandoned regional separatism and turned Lega into a mass party at the national level, with an anti-immigration and Euroskeptic rhetoric (Aknur \& Saylan, 2020, p. 312). The other, Five Star Movement (M5S), was established in 2009 as a populist party

\footnotetext{
7 The situation changed after the period under study, with the 2021 election.

8 The latter is called The Wing (Flügel) and was put under surveillance by the National Security Service (BfD) in 2019. BfD declared it as extremist and it was disbanded. However, BfD warned that the members' activities continued within the party, and sought to classify AfD as a whole as a "suspected case" for extremism. AfD responded by appying to the court, arguing that their constitutional rights were breached (Gehrke, 2021). The court suspended the surveillance until the verdict ("German court", 2021).

9 The party changed its name in 2018.
} 
combining the anti-immigration and Eurosceptic attitudes of the radical right with environmentalist and welfare state orientations of the left. Its resistance to immigration is not based on arguments about ethnic or racial superiority and it advocates both classical liberalism - i.e. privatization - and social democratic policies. This ideological ambiguity makes it difficult to categorize M5S as a left or right wing populist party (Turner, 2013, pp. 179, 184, 205-206).

In Italy, a multiparty system traditionally ruled by coalitions, political parties usually enter elections in alliance, according to their ideological disposition. M5S entered the general elections of 2013 and 2018 without alliances and became the first party in both. LN entered the 2013 election under the center right alliance of Silvio Berlusconi's ${ }^{10}$ The People of Freedom (PdL), which won a victory over the center left alliance under Democratic Party (PD). In 2013 lower house (Chamber of Deputies) elections, LN individually gained only $4.1 \%$ of the votes. In 2018, the center right alliance (37\%) became the first, followed by M5S (32.7\%) and the center left alliance led by PD (22.9\%). Individually, LN (18.8\%) became third after M5S and PD, and first within the center right alliance (Alvarez-Rivera, 2019). LN/Lega also rose from fourth to first in Italy, in 2019 EP elections (European Parliament, 2021).

Following the 2018 election that produced a hung parliament, a heavily technocratic government was formed under independent Guiseppe Conte, comprised of M5S and Lega members, in addition to independent specialists. M5S leader Di Maio and Lega leader Salvini served as Deputy Prime Ministers, as well as Ministers of Interior (Salvini) and Economic Development, Labor and Social Policies (Di Maio), until the cabinet dissolved in September 2019. Hoping for early elections, Salvini withdrew Lega from the coalition (Giuffrida, 2019). Conte formed a second coalition of M5S, social democrats and liberals (PD, LeU, Art.1-SI), which served during the pandemic. The government dissolved again in January 2021, following Conte's resignation after Renzi, the leader of the newly established Italy Alive (IV), ${ }^{11}$ declared that they would withdraw from the government $^{12}$ (Osborne, 2021). The current coalition includes M5S and Lega ${ }^{13}$. Since M5S ideology includes elements of the left and formed coalitions across the ideological spectrum, it is not covered in this study as a PRRP. Only Lega will be examined when it was in opposition.

\section{Main Issues and Policies During the Pandemic}

During the first year of its declaration as an international health emergency, ${ }^{14}$ nearly 102 million cases of Covid19, caused 2.2 million deaths. In Europe, cases exceeded 34 million and deaths approached 740 thousand (WHO, 2021b). Table 1 shows the situation in the four countries.

Table 1

First Year Covid-19 Cases in Selected Countries

\begin{tabular}{l|l|l|l|l}
\hline Country & Cases & Deaths & Deaths/million & Rank $^{*}$ \\
\hline France & $3,178,000$ & 75,862 & 1165 & 3 \\
\hline Italy & $2,542,000$ & 88,279 & 12.278 & 5 \\
\hline Germany & $2,216,000$ & 56,945 & 682 & 7 \\
\hline Austria & 410,000 & 7,636 & 853 & 18 \\
\hline
\end{tabular}

* Rank within WHO European Region, which includes former USSR countries, Israel and non-state territories as well as the states located in the Continent. Source: WHO, 2021a

\footnotetext{
${ }^{10}$ Berlusconi is the leader of Forward Italy (FI), which individually got $14 \%$ of the votes in the 2018 election.

${ }^{11}$ IV was founded by a split from PD in September 2019. Renzi was PD's former leader.

${ }^{12}$ At the time, two ministers of Conte II cabinet were also IV members.

${ }^{13}$ Lega has three ministers. Salvini remained outside the cabinet.

${ }^{14}$ WHO declared Covid-19 as an international health emergency on January 30, 2020, and as a pandemic on March 11,2020 . The data covers the period until January 31, 2021.
} 
Following Russia and the United Kingdom, France was third in terms of cases, closely followed by Italy and Germany. However, the death ratio was much higher in Italy - one of the first countries hit by the pandemic. Austria was much less affected than the others, in terms of the number of cases and deaths.

In the early months, governments started to increase the capacity of their diagnostic and health care systems, and took precautionary measures to reduce transmissions, such as international travel restrictions, quarantines and lockdowns. As economic stagnation followed, they dedicated financial resources to social security and protecting businesses in key sectors (HSRM, 2021). Although preventive measures were relaxed towards the summer, the recurrence of outbreaks and mutations of the virus led to new emergency measures to prevent the spread. Following the progression of the pandemic, schools were opened and closed a number of times. Public events were ended or limited. Social distancing rules were imposed and partial lockdowns were applied (HSRM, 2021). Second wave lockdowns began in Italy and France in October, Germany in November 2020 (Buchholz, 2021). Austria entered the second lockdown the latest, on November 17 (Lardieri, 2020). By January 22, 2021, Austria and Germany were in lockdown on national, Italy on local bases. France was applying national curfews (Buchholz, 2021).

Security and public order became a priority, so that preventive measures took effect. However, beginning with Italy in March, protests have been held against Covid-19 restrictions all over Europe. Demonstrations increased since October 2020, as the second wave led governments to adopt more restrictions. In most cases, far right extremists took part. Moreover, in Italy and Germany, protesters clashed with the police and resorted to violence (European Observatory against Disinformation, 2021).

In Austria, demonstrations were banned due to the limitations on public gatherings. At the end of April, a small group protested mask requirements ("Banned," 2020). In response to the third lockdown (December 26, 2021), FPÖ supporters held a protest march (January 30), despite the government ban. It was held peacefully, yet arrests were made ("Thousands," 2021). In France, anti-mask rallies took place in August, in small numbers. In addition to Covid-19 measures, anti-racism and allegations of Macron's Islamophobia sparked demonstrations during summer and autumn. Since November, pandemic-related internal security measures are protested all over the country on the grounds of media censorship for the use of police powers ("2020: A Year," 2020). In Germany, where the constitutional court outlawed protest bans, protests against Covid-19 related restrictions have taken place since April. According to opinion polls, more than $70 \%$ of the population and $51 \%$ of AfD supporters were in favor of the restrictions ${ }^{15}$ ("Most Germans," 2020). Nonetheless, events escalated in November when protesters, supported by AfD, attempted to enter the federal parliament building ("German Police," 2020). Since March, protests of the restrictions were frequent, widespread and included assaults to the police in Italy (“Anti-lockdown," 2020).

The pandemic is accompanied by economic crisis. The annual growth rate of the EU, already under stress since the 2008-2009 economic crisis, is below 1\% since April 2020. Of the four countries, only Austria's growth rate remained above the EU average. Since July, France's growth almost halted. Germany and Italy face negative growth (Eurostat, 2021a). Unemployment increased slightly in the EU in 2020 (6.5-7.5\%). They are higher than the EU average in France and Italy (around 7-9\%) (Eurostat, 2021b). In the meantime, more severe outcomes are being postponed by government overspending. The combined projections of member states indicate that the Eurozone budget deficit will approach one trillion Euros by the end of 2021, near 9\% of its GDP

\footnotetext{
${ }^{15}$ AfD and Free Democrats (FDP) were the only political parties which did not criticise the protests (Connolly, 2020).
} 
("Eurozone," 2020). In addition to the national level, solutions are being developed at the EU level. The EU adopted the largest recovery package in its history (European Commission, 2021).

\section{PRRPs' Response to the Pandemic and Its Governance}

This section examines the responses of PRRPs in Austria, France, Germany and Italy to the pandemic and its governance. Official Twitter accounts of party leaders ${ }^{16}$ were examined to delineate their positions. The data covers the first year of the pandemic.

Table 2

PRRP Leaders' Tweets about the Pandemic ${ }^{17}$

\begin{tabular}{l|l|l|l|l}
\hline Country & Party & Leaders & Dates & Total \\
\hline Austria & FPÖ & Norbert Hofer & $12.02 .2020-22.01 .2021$ & 44 \\
\hline France & RN & Marine Le Pen & $31.01 .2020-29.01 .2021$ & 166 \\
\hline \multirow{2}{*}{ Germany } & AfD & Jorg Meuthen & $28.02 .2020-29.01 .2021$ & 52 \\
\cline { 3 - 5 } & & Tino Chrupalla & $26.02 .2020-30.01 .2021$ & 46 \\
\hline Italy & Lega & Matteo Salvini & $31.01 .2020-13.10 .2020$ & 134 \\
\hline \multicolumn{2}{l}{ Source: Compiled by the author from Twitter accounts of the leaders } & \\
\hline
\end{tabular}

All leaders approached the pandemic as a major health crisis with long term repercussions in other areas of life - mainly economy, internal security and education. During the initial phase (February-March), their Tweets were mostly informative and positive. The leaders shared what they had learned about the disease, tried to give people hope and expressed solidarity with patients' families, front line workers and Italian people, whom they believed to be affected most severely. Their criticisms were usually constructive and they occasionally supported governments' decisions. ${ }^{19}$ They urged for strong preventive measures (border control, lockdowns, provision of tests and masks), increase of the capacity of the health system and emergency financial support (tax relief, income support) for families and businesses. However, their criticisms of the governments became more severe after March 2020. The following table shows the issues put forward and arguments made by the leaders in their posts.

\footnotetext{
${ }^{16}$ AfD has two leaders (federal spokespersons), both of which were included.

${ }^{17}$ The following hashtags were scanned for the period 30.01.2020-31.01.2021: covid, covid19, covid-19, corona, coronavirus, virus, pandemic, health, crisis. Retweets were omitted. Prefixes covid- and corona- were added to the search, to cover Tweets without the hashtags. The following leaders stopped using hashtags for the virus after these dates: Meuthen-26.08.2020, Chrupalla-22.01.2021, Salvini-13.10.2020.

18 https://twitter.com/norbertghofer; https://twitter.com/MLP_officiel; https://twitter.com/Joerg_Meuthen; https://twitter.com/Tino_Chrupalla; https://twitter.com/matteosalvinimi.

${ }^{19}$ For example, Le Pen supported the Minister of Interior for the first wave confinement measures (2020, March 17).
} 
Table 3

PRRP Leaders' Criticisms of Pandemic Governance*

\begin{tabular}{|c|c|c|c|c|c|}
\hline Argument & Issue & FPÖ & AfD & $\mathbf{R N}$ & Lega \\
\hline \multirow[t]{8}{*}{ Insufficient } & Border control & $\mathrm{x}$ & $\mathbf{x}$ & $\mathbf{x}$ & $\mathbf{x}$ \\
\hline & Public order (prisoners, immigrants) & & & $\mathbf{x}$ & $\mathbf{x}$ \\
\hline & Testing capacity & $\mathrm{x}$ & & $\mathbf{x}$ & $\mathrm{x}$ \\
\hline & Mask provision & $\mathrm{x}$ & & $\mathbf{x}$ & $\mathbf{x}$ \\
\hline & Vaccine provision & $\mathrm{x}$ & $\mathrm{x}$ & $\mathrm{x}$ & $\mathrm{x}$ \\
\hline & Treatment capacity & $\mathrm{x}$ & $\mathrm{x}$ & $\mathbf{x}$ & $\mathbf{x}$ \\
\hline & Protection of risk groups & $\mathbf{x}$ & $\mathrm{x}$ & $\mathrm{x}$ & $\mathrm{x}$ \\
\hline & Economic support & $\mathbf{x}$ & $\mathbf{x}$ & $\mathbf{x}$ & $\mathbf{x}$ \\
\hline \multirow[t]{5}{*}{ Excessive } & Ban on public gatherings & $\mathrm{x}$ & $\mathbf{x}$ & & \\
\hline & Regional threat-level system & $\mathbf{x}$ & $\mathrm{x}$ & & \\
\hline & Mask requirement & & $\mathbf{x}$ & & \\
\hline & Closure of schools & $\mathbf{x}$ & $\mathbf{x}$ & & $\mathrm{x}$ \\
\hline & Closure of hotels, restaurants, shops & $\mathbf{x}$ & $\mathbf{x}$ & $\mathrm{x}$ & $\mathrm{x}$ \\
\hline \multirow[t]{5}{*}{ Wrong } & Undemocratic decision-making & $\mathbf{x}$ & $\mathbf{x}$ & $\mathbf{x}$ & $\mathbf{x}$ \\
\hline & Breach of fundamental rights/constitution & $\mathbf{x}$ & $\mathbf{x}$ & & \\
\hline & Intrusion of privacy/data & $\mathrm{x}$ & $\mathrm{x}$ & $\mathrm{x}$ & \\
\hline & Supporting immigrants & & $\mathbf{x}$ & & $\mathbf{x}$ \\
\hline & Involvement of the EU in recovery & & $\mathbf{x}$ & $\mathrm{x}$ & $\mathbf{x}$ \\
\hline
\end{tabular}

${ }^{{ }^{*} I s s u e s}$ mentioned for over one month are indicated in bold.

Source: Compiled by the author from Twitter posts of the leaders

The leaders blamed the governments for lacking a sound strategy, acting inconsistently and indecisively, hiding truths and failing to provide enough for the people. They continuously demanded stricter border controls, increasing the protection of risk groups such as the elderly, the treatment capacity and economic support for families and small businesses. When vaccines became available, they urged the governments to provide more and sooner. From April 2020 onwards, in addition to insufficiency, they criticized the governments for applying strict measures which they found excessive. Whereas FPÖ and AfD leaders criticized almost all aspects of preventive measures, $\mathrm{RN}$ and Lega leaders began criticizing these much later, following the second wave precautions adopted in late 2020 .

Consistent with PRRPs' anti-establishment discourse (Mudde \& Rovira Kaltwasser, 2017, pp. 5-7), even when they agreed with the contents, all leaders argued that governments abused their power in how they issued emergency measures. They demanded the involvement of the opposition and the public in these decisions. While RN and Lega leaders did not object preventive measures until late 2020, FPÖ and AfD continuously alleged that their governments acted against the constitution and breached fundamental rights by imposing lockdowns and other restrictions on social distancing. However, despite the apparent involvement of FPÖ and AfD in Covid demonstrations in critique of such measures ("German Police" 2020; "Thousands," 2021), the leaders did not openly support the protesters.

In line with their Eurosceptic attitude (Mudde \& Rovira Kaltwasser, 2017, pp. 34-35; van Kessel, 2015, p. 27; Vasipoulou, 2011), the leaders except FPÖ leader Hofer, ${ }^{20}$ opposed the role of the EU in recovery plans, which they believed was a matter of sovereignty. PRRPs anti-immigration attitude was also reflected in their posts. However, it was rarely mentioned in the context of the pandemic, except by Lega leader Salvini. Specific arguments of the leaders are presented below.

\footnotetext{
${ }^{20}$ Hofer also criticized the EU - i.e. for raising budget contributions (2020, July 21), but not in the context of the pandemic.
} 
FPÖ: Although he found the provision of masks by the government necessary, Hofer opposed mask wearing requirements after the first months of the pandemic. He characterized safety measures as "Austrofaschism" (2020, September 16), a totalitarian approach controlling many aspects of citizens' lives in violation of their fundamental rights. He advocated amnesty for the breach of control orders by the public (2020, July 22). $\mathrm{He}$ argued that the regional threat levels were not as high as the government declared, causing unnecessary confinement (2020, September 15). He advocated a "hardship allowance" for having to wear masks at the workplace (2020, September 21). Hofer was the only leader who didn't mention EU or immigration issues in the context of the pandemic.

AfD: Except financial support for small businesses and unemployed workers, the leaders focused on the excessiveness of government intervention rather than its insufficiency. They did not oppose the initial lockdown. ${ }^{21}$ However, since May, they have argued that the level of threat was exaggerated. According to this narrative, as Chrupalla claimed, the "corona madness" was being played by the "panic orchestra" of the political mainstream (2020, October 16). Continued lockdowns, closing of schools and businesses endangered the economy and future generations. Moreover, the emergency measures were characterized as "totalitarian" (Meuthen, 2020, August 29, October 29). By banning public gatherings and protests, forcing people to wear masks and intruding their private lives, the leaders argued that the government abused its power and violated fundamental rights. ${ }^{22}$ Unlike other leaders in the study, Meuthen's anti-immigration rhetoric was openly racist and Islamophobic. He argued that "Arab clans...prey on German society" by applying for Corona aid (2020, April 29) and insinuated that Muslim associations committed fraud with that aid (2020, October 23). AfD leaders also opposed EU-based efforts to mitigate the crisis. Meuthen, who initially sent solidarity messages to Italy (2020, March 15), criticized Germany's financial support to Italy through the EU (2021, January 5).

RN: For the most part of the year, Le Pen advocated strict preventive measures. She supported efforts for mass testing, all of the lockdowns, closure of schools, mask wearing and social distancing obligations. In fact, she demanded further restrictions, such as warning against ending the first lockdown too soon, with the exception of places of worship (2020, May 3). She did not initially oppose lockdowns during the second wave. She only opposed prolonging the ban on public cultural activities (2021, January 17) and opening of restaurants (2021, January 7) at the end of the first year. Le Pen also criticized the government for creating risks for public order, by releasing prisoners (2020, February 29) and not suppressing immigrants' riot against the first lockdown, more harshly (2020, May 4).

Lega: Salvini believed that Italy experienced the worst in terms of mortality rates and the severity of economic crisis (2021, January 18). Accordingly, he did not object preventive measures as excessive and didn't argue that citizens' rights were breached by emergency measures. Like Le Pen, he opposed the closure of schools (2020, October 8 ), restaurants and shops (2020, November 6) relatively late. Even then, he reminded the necessity of following the rules for protection (2020, November 6) and criticized the government for not taking enough precautions at schools (2021, January 6). As Le Pen, he mentioned the releasing of prisoners (2020, February 8 , November 22) and the protests of immigrants at reception centers (2020, October 7$)$ as public security risks. Unlike Le Pen, he didn't advocate prolonging preventive measures at the national level during the second wave. On a regional basis, contrary to FPÖ and AfD leaders, he criticized the government for underestimating, rather than overstating the threat levels (2021, January 15).

\footnotetext{
${ }^{21}$ While Chrupalla suggested the government to enable paid leave of absence to parents (2020, March 12), Meuthen criticised young people for disobeying rules by organizing Corona parties (2020, March 17).

${ }^{22}$ AfD applied to the Constitutional Court for the annulment of mask obligations (Chrupalla, 2020, October 7) and planned to apply for the Civil Protection Act amendments that introduced further measures for public safety (Chrupalla, 2020, November 20).
} 
From June onwards, Salvini repeated his opposition to immigration multiple times every month. During his term as the Minister of Interior (2019), he had prevented the landing of asylum seekers rescued at sea, which caused the senate to lift his immunity for prosecution in July (Associated Press in Rome, 2020). The trial began in October (Tondo, 2020) ${ }^{23}$. Like the other leaders, he criticized the government for deficiencies in border control from the beginning. Yet, most of his arguments were directed at asylum seekers. Salvini blamed asylum seekers - whom he characterized as illegal immigrants and fake refugees (2020, July 26) - for bringing sickness (2020, June 24, July 21, August 26, September 27, October 13), escaping control (2020, July 26, August 1) and violence (2020, October 7, 15), while he blamed the government for allowing them in Italian territory. Although Le Pen also reported that immigrants were rioting (2020, May 4), she did not specify them as health risks and did not blame the government as a facilitator. Another aspect of Salvini's posts apart from other PRRP leaders was the blaming of China and its communist regime for the pandemic (2020, June 6, October 21, November 21).

\section{Popular Support During the Pandemic}

This section examines the popular support in the four countries for major parties in government and opposition, together with PRRPs, during the first year of the pandemic. The table below presents the last national or presidential election results (2017-2019) and survey results during the pandemic. The survey data is provided by Politico, which systematically gathers the results of numerous statistically reliable opinion polls in each European country, and processes these into a weighted average presented over time (Politico, 2021a). Four dates were chosen to cover voting intentions: the beginning of the pandemic (January 30, 2020), the month following the first lockdown orders and the beginning of severe criticism of governments by PRRP leaders (May 1, 2020), the month after the second wave lockdowns started in all of the countries (December 1, 2020), and the end of the first year (January 31, 2021).

Table 4

Popular Support for Major Parties and PRRPs Before and During the Pandemic*

\begin{tabular}{|c|c|c|c|c|c|c|}
\hline Country & Parties & Elections & 30.01 .2020 & 01.05 .2020 & 01.12 .2020 & 31.01 .2021 \\
\hline \multirow[t]{5}{*}{ Austria } & Gov. & 52 & 55 & 61 & 52 & 47 \\
\hline & ÖVP & 38 & 39 & 44 & 40 & 37 \\
\hline & Greens & 14 & 16 & 17 & 12 & 10 \\
\hline & SPÖ & 21 & 17 & 18 & 22 & 23 \\
\hline & FPÖ & 16 & 13 & 11 & 14 & 16 \\
\hline \multirow[t]{3}{*}{ France $^{\star *}$} & LREM & 24 & 28 & 28 & 24 & 24 \\
\hline & $L R$ & 20 & 11 & 12 & 14 & 15 \\
\hline & $\mathbf{R N}$ & 21 & 27 & 26 & 26 & 26 \\
\hline \multirow[t]{6}{*}{ Germany } & Gov. & 54 & 40 & 54 & 51 & 51 \\
\hline & $\mathrm{CDU} / \mathrm{CSU}$ & 33 & 27 & 38 & 36 & 36 \\
\hline & SPD & 21 & 13 & 16 & 15 & 15 \\
\hline & $F D P$ & 11 & 8 & 6 & 7 & 7 \\
\hline & Greens & 9 & 22 & 16 & 19 & 19 \\
\hline & AfD & 13 & 13 & 10 & 9 & 9 \\
\hline \multirow[t]{5}{*}{ Italy } & Gov. ${ }^{* * *}$ & 52 & 35 & 37 & 36 & 35 \\
\hline & M5S & 33 & 15 & 16 & 15 & 15 \\
\hline & $\mathrm{PD}$ & 19 & 20 & 21 & 21 & 20 \\
\hline & $F d I$ & 4 & 11 & 14 & 14 & 16 \\
\hline & Lega & 18 & 31 & 28 & 24 & 24 \\
\hline
\end{tabular}

*: Government parties are indicated at the top, PRRPs are indicated in bold, other opposition parties are indicated in italic. The values show percentages.

$* *$ : Presidential elections (first round of the 2017 election, voting intentions for 2022)

$* * *$ : Total percentage of government parties included in the table.

Sources: Alvarez-Rivera, 2019; Politico, 2021b

\footnotetext{
${ }^{23}$ It was dismissed by the judge in May 2021. Another trial in Palermo begins in September 2021 ("Italy judge", 2021).
} 
Before the pandemic, popular support had already changed for all parties, since the last elections. Austrian and French governments entered the pandemic in a slightly better position, while German and Italian governments had faced significant losses in their popular support. With the pandemic, all governments' popularity increased by May 2020, when the first preventive measures (February-April) took effect. In Austria and France, governments surpassed their election level. In Germany, the support for the grand coalition increased back to its election level. In Italy, the main coalition partners' support remained far lower than the last election results, despite a slight increase in their support from January to May 2020.

However, during the second half of 2020, government support decreased in all countries. In Austria, both government parties ended up with lower support than the last elections. In France, Macron's support reduced to the election level by December. In Germany, government support slightly decreased after May, yet remained close to the election level, which was much higher than it was at the beginning of the pandemic. Main coalition partner CDU/CSU performed much better than SPD, surpassing its performance in the last election. In Italy, popular support reduced only slightly for the main coalition partners, returning to its level at the beginning of the pandemic.

Popular support for the PRRPs had decreased in Austria, remained the same in Germany and increased significantly in France and Italy before the pandemic. The changes during the first year of the pandemic were also different in each country, except for the initial period. Whereas governments' support increased towards May 2020, PRRPs' support decreased by 1-3\% in all countries. From May 2020 to the end of the first year, except for FPÖ, PRRPs' popular support either decreased or remained the same. However, the situation looks different when the end of the first year is compared to the last election results. FPÖ's support increased back to its election level, AfD's support decreased considerably, and both RN and Lega ended up in a much better position than the last elections.

Major opposition parties other than the PRRPs had increased their support before the pandemic in Germany and Italy. Greens and Fdl had become likely to be the first parties in opposition replacing FDP and FI, if elections were held. In Austria and France, SPÖ and LR had lower popular support at the beginning of the pandemic than the last elections. From May 2020 to the end of the first year, the popular support for the main opposition parties other than the PRRPs increased, as popular support for governments were reduced. In France and Italy, PRRPs have a much better chance for taking part in government or becoming the main opposition than mainstream parties, in the next national or presidential elections.

\section{Discussion and Conclusion}

The first question this study sought to answer was how PRRPs in Europe responded to the pandemic and its governance. Given that they had sustained a politics of anxiety over the previous crises, it is important to find out how they have reacted to the current crisis. Did they accentuate it, triggering public fears? More important, did they keep emphasizing the similar themes they had capitalized upon during the financial and refugee crises, or did they alter their discourse?

The findings from the examination of PRRP leaders' Twitter posts show that PRRPs continued with their antiestablishment, anti-immigration, nationalistic and Eurosceptic arguments. However, the prioritization of these themes differed in the pandemic context. Especially after March 2020, their anti-establishment rhetoric, refitted to issues about pandemic governance, took priority. They continued to oppose immigration and immigrant rights, yet these were not pronounced as a major part of the pandemic problem. Lega leader Salvini was an exception in this regard. He continuously framed immigration in relation to the pandemic, by blaming irregular migrants for spreading disease and disrupting public order. PRRP leaders continued to propagate 
economic protectionism and welfare chauvinism, in relation to the economic crisis that accompanied the pandemic. The leaders also voiced their mistrust in the EU for mitigating the crisis. However, like immigration, the EU did not take much place in their Tweets about the pandemic. In other words, although the ingredients remained the same, PRRPs altered their prescriptions. However, their arguments were inconsistent and differentiated.

Although all leaders agreed that the pandemic constitutes a major crisis which requires emergency action on many fronts, their criticism of pandemic governance lacked coherence. They blamed the governments for insufficiency and excessiveness at the same time. On the one hand, they argued that the governments did not take decisions firmly or fast enough, such as closing the borders to prevent the spread of the disease. On the other, they expected emergency decisions to be taken after long deliberations, appeasing every segment of the society, including their parties. They demanded risk groups to be protected, while they objected the measures for such protection, such as closing down of businesses where people may come into contact at close proximity.

Two different positions appeared among the PRRPs on preventive measures. RN and Lega leaders did not object mask wearing requirements, social distancing rules or lockdowns during most of the first year of the pandemic. Moreover, they advocated firm measures to ensure public order so that the rules were followed. However, FPÖ and AfD leaders objected to such measures, after the initial phase of restrictions applied in February and March 2020. Furthermore, they utilized fundamental rights to legitimize their position, inciting civil disobedience. Yet, like RN and Lega leaders, they demanded capacity increases and supportive measures. In other words, they denied the nature of the health emergency while they criticized their governments' response to the same emergency as insufficient.

The second question the study posed was how the PRRPs' positions on the pandemic and its governance reflected on their popular support. Does the pandemic pose an opportunity or threat for them in the coming elections? The answer changed during the course of the pandemic and became obscured by differences between the countries and political parties after the initial months. Therefore, no generalizations could be drawn. Nonetheless, there was a temporary development in both government and PRRP support that is worth mentioning.

During the initial phase of the pandemic, whereas popular support for governments either remained the same (France) or increased (Austria, Germany and Italy), it decreased for all PRRPs, despite variance in the amount of change (1-3\%). The former finding is supported by various studies conducted in Europe before June 2020, which found out that voting intentions for governments, as well as trust in governments and existing institutions increased in this period (Blais et al., 2020, p. 2). Since the core tenet of PRRPs is challenging the status quo and the political mainstream, it is not surprising that the increase in government support coincided with decrease in PRRP support. As the pandemic and related problems continued, popular support started to become differentiated.

During the second half of 2020, preventive measures were first eased, then reasserted in the four countries. Although governments acted similarly, popular support varied for all political parties. Even when developments during 2021 are considered, it is not possible to discern any common trend. In Austria, the ÖVPGreens government lost its support to SPÖ and FPÖ by end of 2020. ${ }^{24}$ In Germany, although the popular support increased for CDU/CSU, SPD lost its potential voters to Greens and AfD lost almost a third of its

\footnotetext{
${ }^{24}$ FPÖ support surpassed the last election level (18\%) by September 2021 (Politico, 2021b).
} 
previous support by the end of 2020. ${ }^{25}$ In France and Italy, PRRPs became the first parties in terms of popular support by the end of 2020 (26-24\%), but lost part of that support by September 2021 (21-20\%) (Politico, $2021 b){ }^{26}$

The findings demonstrate that while PRRPs preserved their previous discursive strategy of disruptive criticism towards the ability of their governments to mitigate crises (Kriesi \& Pappas, 2015; Poli, 2016; Ellinas, 2018, pp. 391-392; Mudde \& Rovira Kaltwasser, 2017, p. 106), the pandemic did not provide an opportunity for PRRPs to increase their popular support. On the contrary, they lost potential voters during the initial months and not all of them recovered in the following months. At this juncture, it is necessary to ask what makes the pandemic different than the previous crises Europe went through.

The Covid-19 pandemic began as, and remains to be, an unprecedented health crisis. People feared for their lives before they feared loss of earnings. As such, the increase in government support all over Europe in the initial months may be explained by "rallying around the flag effect". The concept was coined by studies in the field of international security, as a result of observations on popular support during situations involving war. In the USA and other countries, such crises triggered a resurge of patriotism that overcame political divisions (Murray, 2017). Similarly, during the first months, having witnessed the situation in countries where the pandemic spread quickly such as China and Italy, people depended on their current governments, institutions and leaders to provide safety and stability (Iniguez et al., 2020; Blais et al., 2020). Severe authoritative measures were accepted without reservation (Woods et al., 2020, p. 811). The concurrent loss of support for PRRPs may be explained by the fact that PRRPs are first and foremost, challenger parties that seize opportunity from turmoil, which people sought to avoid.

The pandemic also became a multidimensional crisis, affecting most areas of people's lives and futures, for a much longer time than anyone had prepared for. Although the capacity of the health sector is being developed by governments, the economic recession cannot be overcome easily. The effects are currently being postponed by recovery packages ("Eurozone," 2020; European Commission, 2021). Yet, no amount of credit or income support would prevent bankruptcies or guarantee stable employment in many sectors, as long as lockdowns, curfews and other controls are continued. The effect of lockdowns in fields such as social psychology and education, remain to be seen. Since the crisis took its toll on people's circumstances, popular support is no longer automatic for governments. This situation has not provided all PRRPs with the same opportunity. The future of European PRRPs through this crisis, depend on factors specific to each country and political party, the effects of which remain to be seen.

The findings indicate that the discursive frameworks which European PRRPs had used to challenge the mainstream in the previous crises, have begun to differentiate with the current one, as well as the political opportunity structure in each country. However, there are a number of caveats that preclude generalizations. First, the study is limited by its focus on the pandemic. The change in party discourses were discovered upon leaders' social media posts specifically about the pandemic and crisis. More comprehensive results may be derived from studies that focus on the themes, such as economic protectionism and immigration in leaders' public speeches not only about, but also during the pandemic. Second, the time frame of the study is inadequate to determine the future. It should not be inferred from the similarity of governments' responses during the progression of the pandemic, that the crisis has a definite direction or timely solution. Despite developments in medicine, the prevention and treatment of the virus are still not provided for. Therefore, it is probable that

\footnotetext{
${ }^{25}$ The situation changed after the period under study. SPD became the first party (25.7\%), followed by CDU/CSU (24.1\%), Greens (14.8\%), FDP (11.5\%) and $\mathrm{AfD}(10.3 \%)$ in the 2021 general election (September 26).

${ }^{26}$ Currently, Le Pen is second after Macron (25\%) and Lega shares the first rank with FdI. (Politico, 2021b).
} 
policy responses and public reactions will continue to change. The findings show that just as governments, the PRRPs were caught unprepared and altered their positions numerous times within a single year. Therefore, new trends in political discourse and alignment are likely to appear in the longer run.

\section{References}

2020: A Year of Protests and Civil Disobedience. (2020, 28 December). France24. Retrieved from: https://www.france24.com/en/europe/20201228-2020-a-year-of-dissent-and-civil-disobedience

AfD: What You Need to Know about Germany's Far Right Party. (2019, 28 October). DW. Retrieved from: https://www.dw.com/en/afd-what-you-need-to-know-about-germanys-far-right-party/a-37208199

Aknur, M. and Saylan, İ. (2020). Avrupa demokrasisine yönelik güncel bir tehdit: Popülist radikal sağın yükselişi [A current threat to European democracy: The rise of populist radical right]. Ankara Avrupa Çalısmaları Dergisi, 18(2), 289-324. doi: 10.32450/aacd.676473

Albertazzi, D. and McDonnell, D. (2008). Introduction: The sceptre and the spectre. In D. Albertazzi, and D. McDonnell (Eds.), Twenty-First century populism: The spectre of Western European democracy (pp. 511). Basingstoke: Palgrave Macmillan.

Alvarez-Rivera, M. (2019, 21 October). Election resources on the internet. Retrieved from: http://electionresources.org/

Anti-lockdown Protesters Turn on the Police in Spain and Italy. (2020, 2 November). The Times. Retrieved from: https://www.thetimes.co.uk/article/anti-lockdown-protesters-turn-on-the-police-in-spain-anditaly-3h2qsvjq3

Associated Press in Rome. (2020, 30 July). Italy's senate votes to lift Matteo Salvini's immunity from prosecution. The Guardian. Retrieved from: https://www.theguardian.com/world/2020/jul/30/italyssenate-votes-to-lift-matteo-salvinis-immunity-from-prosecution

Austria Election: Sebastian Kurz's People's Party in Convincing Win. (2019, 30 September). BBC News. Retrieved from: https://www.bbc.com/news/world-europe-49867930

Austria: Herbert Kickl Elected to Lead Far Right Freedom Party. (2021, 20 June). DW. Retrieved from: https://www.dw.com/en/austria-herbert-kickl-elected-to-lead-far-right-freedom-party/a-57971160

Banned Vienna Protest Against Lockdown Draws 200. (2020, 24 April), US News. Retrieved from: https://www.usnews.com/news/world/articles/2020-04-24/banned-vienna-protest-against-lockdowndraws-200

Blais, A., Bol, D., Giani, M. and Loewen, P. (2020). The effect of COVID-19 lockdowns on political support: Some good news for democracy?. European Journal of Political Research, 60(2), 497-505. doi:10.1111/1475-6765.12401

Bodlos, A. and Plescia, C. (2018). The 2017 Austrian snap election: a shift rightward. West European Politics, 41(6), 1354-1363. doi: 10.1080/01402382.2018.1429057

Bushholz, K. (2021, 22 January). Europe stays in lockdown mode. Statista. Retrieved from: https://www.statista.com/chart/23330/coronavirus-restrictions-europe-map/

Ellinas, A. A. (2018). Media and the radical right. In J. Rydgren (Ed.), The Oxford handbook of the radical right (pp. 390-410). New York: Oxford University Press. 
Connolly, K. (2020, 3 August). Berlin protests against coronavirus rules divides German leaders. The Guardian. Retrieved from: https:/www.theguardian.com/world/2020/aug/03/berlin-protests-againstcoronavirus-rules-divide-german-leaders

European Commission. (2021). A recovery plan for Europe. Retrieved from: https://ec.europa.eu/info/strategy/recovery-plan-europe_en

European Observatory against Disinformation. (2021, 11 November). The three common threads that link anti-lockdown protests in Europe'. Retrieved from: https://www.disinfobservatory.org/the-threecommon-threads-that-link-anti-lockdown-protests-in-europe/

European Parliament. (2021). 2019 European election results. Retrieved from: https://www.europarl.europa.eu/election-results-2019/en/tools/comparative-tool/

Eurostat. (2021a). Covid-19: Economy. Retrieved from: https:/ec.europa.eu/eurostat/web/covid-19/economy

Eurostat. (2021b). Covid-19: Society and work. Retrieved from: https://ec.europa.eu/eurostat/web/covid19/society-work

Eurozone Budget Deficits Rise Nearly Tenfold to Counter Covid-19 Pandemic. (2020, 19 October). Business Standard. Retrieved from: https://www.business-standard.com/article/international/eurozone-budgetdeficits-rise-nearly-tenfold-to-counter-covid-19-pandemic-120101901410_1.html

Gehrke, L. (2021, 22 January). Germany's far-right AfD files lawsuits to avoid Security Service surveillance. Politico. Retrieved from: https:/www.politico.eu/article/germany-afd-lawsuits-against-securityservice-surveillance/

German Court Suspends Surveillance for Far Right AfD, for Now. (2021, 5 March). DW. Retrived from: https://www.dw.com/en/german-court-suspends-surveillance-of-far-right-afd-for-now/a-56785125

German Police Clash with Protesters angry at Merkel's Coronavirus Law. (2020, 18 November). Reuters. Retrieved from: https://www.reuters.com/article/health-coronavirus-germany-protestsidINKBN27Y15T

Giuffrida, A. (2019, 20 August). Italian PM resigns with attack on 'opportunist' Salvini. The Guardian. Retrieved from: https://www.theguardian.com/world/2019/aug/20/italian-pm-expected-resigngiuseppe-conte

Goodwin, M.J. and Dennison J. (2018). The radical right in the United Kingdom. In J. Rydgren (Ed.), The Oxford handbook of the radical right (pp. 739-769). New York: Oxford University Press.

Health System Response Monitor. (2021). Compare countries. Retrieved 31 January, 2021, from: https://www.covid19healthsystem.org/searchandcompare.aspx

Henley, J. (2020, 6 July). France's new prime minister keeps key figures in reshuffled cabinet. The Guardian. Retrieved from: https://www.theguardian.com/world/2020/jul/06/france-new-prime-minister-jeancastex-reshuffled-cabinet-macron

Iniguez, G., Weizman, J., Fidanovski, K., Palowski, N. and Boucart, T. (2020, 22 April). When our loss is their gain: Covid-19 and government popularity around Europe. The New Federalist. Retrieved from: https://www.thenewfederalist.eu/when-our-loss-is-their-gain-covid-19-and-government-popularityaround?lang=fr

Italy Judge Rules Salvini Should not Stand Trial in Migrant Ship Case. (2021, 14 May). Reuters. Retrieved from: https://www.reuters.com/world/europe/italy-judge-rules-salvini-should-not-stand-trial-migrant-shipcase-2021-05-14/ 
Kriesi, H. and Pappas, T.S. (Eds.). (2015). European populism in the shadow of great recession: Studies in political science. Colchester: ECPR Press.

Lardieri, A. (2020, 17 November). Austria enters national lockdown after seeing record Coronavirus cases. US News. Retrieved from: https://www.usnews.com/news/health-news/articles/2020-11-17/austria-enterssecond-national-lockdown-after-seeing-record-coronavirus-cases

Most Germans on board with coronavirus lockdown. (2020, 16 December). DW. Retrieved from: https://www.dw.com/en/most-germans-on-board-with-coronavirus-lockdown/a-55965289

Mudde, C. (2017). Populism: An ideational approach. In Rovira Kaltwasser, C., Taggart, P., Espejo, P.O. and Ostiguy, P. (Eds.), The Oxford handbook of populism (pp. 27-47). Oxford: Oxford University Press.

Mudde, C. and Rovira Kaltwasser, C. (2017). Populism: A very short introduction. Oxford: Oxford University Press.

Murray, S. (2017, 28 June). The "rally-'round-the-flag" phenomenon and the diversionary use of force. Oxford Research Encyclopedia of Politics. Retrieved from: https://oxfordre.com/politics/view/10.1093/acrefore/9780190228637.001.0001/acrefore9780190228637-e-518. doi: 10.1093/acrefore/9780190228637.013.518

Osborne, S. (2021, 27 January). Italian prime minister Giuseppe Conte resigns in tactical bid to form new coalition. The Independent. Retrieved from: https://www.independent.co.uk/news/world/europe/italyprime-minister-giuseppe-conte-resigns-b1793100.html

Öner, S. (2014). Different manifestations of the rise of far-right in European politics: The cases of Germany and Austria. Marmara Journal of European Studies, 22(2), 85-106. Retrieved from: https://dergipark.org.tr/tr/pub/maruaad/issue/349/1863

Poli, M.D. (2016). Contemporary populism and the economic crisis in Western Europe. Baltic Journal of Political Science, 5, 40-52. doi: 10.15388/BJPS.2016.5.10335

Politico (2021a). How POLITICO poll of polls tracks polling trends across Europe. Retrieved from: https://www.politico.eu/article/how-politico-poll-of-polls-tracks-polling-trends-across-europe/

Politico (2021b). Poll of polls. Retrieved from: https://www.politico.eu/europe-poll-of-polls/

Thousands protest in Vienna as far-right march on COVID measures banned. (2021, 31 January). Reuters. Retrieved from: https://www.reuters.com/article/us-health-coronavirus-austria-demoidUSKBN2A00K5

Tondo, L. (2020, October 2). Matteo Salvini goes on trial over migrant kidnapping charges. The Guardian. Retrieved from: https://www.theguardian.com/world/2020/oct/02/matteo-salvini-set-to-be-tried-overmigrant-kidnapping-charges-italy

Top Macron Ally Bayrou quits French government. (2017, 21 June). BBC News. Retrieved from: https://www.bbc.com/news/world-europe-40351918

Tournier-Sol, K. (2020). From UKIP to the Brexit party: The politicization of European integration and disruptive impact on national and European arenas. Journal of Contemporary European Studies, 29(3), 380-390. doi: 10.1080/14782804.2020.1785849

Turner, E. (2013). The 5 Star Movement and its discontents: A tale of blogging, comedy, electoral success and tensions. Interface, 5(2), 178-212. Retrieved from: https://www.semanticscholar.org/paper/The-5-StarMovement-and-its-discontents-\%3A-A-tale-of-Turner/0e902c899cdf92a4c92df658526ccb36db096dfc 
van Kessel, S. (2015). Populist parties in Europe: Agents of discontent?. Basingstoke: Palgrave Macmillan.

Vasipoulou, S. (2011). European integration and the radical right: Three patterns of opposition. Government and Opposition, 46(2), 223-244. doi: 10.1111/j.1477-7053.2020.01337.x

Verbeek, B. and Zaslove, A. (2017). Populism and foreign policy. In Rovira Kaltwasser, C., Taggart, P., Espejo, P.O. and Ostiguy, P. (Eds.), The Oxford handbook of populism (pp. 384-405). Oxford: Oxford University Press.

Weyland, K. (2017). Populism: a political-strategic approach. In Rovira Kaltwasser, C., Taggart, P., Espejo, P.O. and Ostiguy, P. (Eds.), The Oxford handbook of populism (pp. 48-72). Oxford: Oxford University Press.

Woods, E. T., Schertzer, R., Greenfeld, L. Hughes, C. and Miller-Idriss, C. (2020). COVID-19, nationalism, and the politics of crisis: A scholarly exchange. Nations and Nationalism, 26(4), 807-825. doi: 10.1111/nana.12644.

World Health Organization. (2021a). COVID-19 situation in the WHO European region. Retrieved 31 January, 2021, from: https://who.maps.arcgis.com/apps/opsdashboard/index.html\#/ead3c6475654481ca51c248d52ab9c61

World Health Organization. (2021b). WHO Coronavirus disease (COVID-19) dashboard. Retrieved 31 January, 2021, from: https://covid19.who.int/\#

\section{Genişletilmiş Özet}

\section{Amaç}

Bu çalışmanın amacı, Covid-19 pandemisi krizinde, Avrupa'daki Popülist Radikal Sağ Partilerin (PRSPlerin) pandemi ve pandemi yönetimine tepkileri ile popüler destek durumunu ortaya çıkarmak ve geçmiş eğilimler ışığında, yeni yönelimleri belirlemektir. Çalışmada ilk olarak, PRSPlerin pandemi odağındaki söylemleri değerlendirilmektedir. Avrupa'nın geçmiş dönemde yaşadığı krizlerde ana akım ve göç karşıtı, refah milliyetçisi ve Avrupa şüphecisi bir söylem çerçevesiyle yükselişe geçen bu partiler, yeni ve çok boyutlu bir kriz olan pandemiye ve hükümetlerin aldığı önlemlere nasıl tepki vermiştir? İkinci olarak, pandeminin PRSPlerin popüler desteğine etkisi araştırılmaktadır. Pandemi, geçmiş krizlerde ana akıma rakip hale gelen bu partiler için bir firsat mı, yoksa bir tehdit mi olmuştur? Çalışmada elde edilen bulgularla, PRSPlerin Avrupa'daki yükseliş eğilimi ve krizlerle ilişkisi yeniden değerlendirilmektedir.

\section{Tasarım ve Yöntem}

Keşifsel amaçlı bu çalışma, karşılaştırmalı ve niteliksel olarak tasarlanmıştır. Araştırma, Covid-19 virüsünün Dünya Sağlık Örgütü tarafından uluslararası bir sağlık krizi olarak nitelendirildiği 30 Ocak 2020 tarihinden 31 Ocak 2021'e dek, pandeminin ilk yılını kapsamaktadır. Avrupa'daki PRSPlerin söylemi ve popüler desteği, dört örnek ülke üzerinden incelenmektedir: Avusturya, Fransa, Almanya ve İtalya. Bu dört ülkedeki PRSPler, benzer söylem unsurlarını kullanarak, geçtiğimiz on yıllık dönemde yükselişe geçmiştir (Vasipoulou, 2011; van Kessel, 2015; Mudde \& Rovira Kaltwasser 2017). Bazıları, pandemi öncesinde koalisyonlarda yer almışlarsa da (Avusturya, İtalya), çalışmanın kapsadığı dönemde muhalefettedirler. Diğer bir deyişle, hükümetleri eleştirebilecek konumdadırlar. Pandemi döneminde dört ülkenin hükümetleri, yakın tarihlerde, birbirine benzer acil durum önlemleri uygulamışlardır. Bu faktörler, dört ülkedeki PRSPlerin söylemleri ve popüler destekleri arasındaki benzerlik ve farklılıkları ortaya çıkarmayı kolaylaştırmaktadır. 
Lider partisi niteliğindeki PRSPler, siyasi propaganda yöntemi olarak lideri seçmenlerle doğrudan buluşturan sosyal medyaya ağırlık vermektedir (van Kessel, 2015, ss. 14-15; Weyland, 2017). Buna uygun olarak, parti söylemleri, liderlerinin resmi Twitter hesaplarında pandemi ve kriz hakkında yayınladıkları iletiler üzerinden incelenmektedir. Belirlenen iletilerde liderlerin pandemi ve yönetimi üzerine yorumlarının yanında, geçmişte bu partilerin kullandığı temel söylem unsurlarının ağırlığı ve önceliği irdelenmektedir.

Popüler destekteki değişimler, ulusal düzeyde sorgulanmaktadır. Örnek ülkelerde pandemi döneminde bazı yerel ve bölgesel seçimler ile referandumlar yapılmıştır. Ancak sonuçlar bölge ve seçim konusu itibariyle ulusal düzeydeki seçmen davranışından farklı özellikler gösterebileceğinden, seçim sonuçları yerine kamuoyu yoklamaları tercih edilmiştir. PRSPlerin yanı sıra, hükümet ve muhalefetteki güçlü ana akım partilerin popüler desteği de kapsanmaktadır. Son genel veya başkanlık seçim sonuçları ile pandemi sürecinin çeşitli aşamalarındaki kamuoyu yoklama sonuçları bir arada değerlendirilerek, popüler destekteki eğilimler tespit edilmeye çalışılmaktadır.

\section{Bulgular}

PRSP liderlerinin söylem incelemesinde, bu partilerin geçmiş on yıllık dönemde benimsedikleri temel söylem unsurlarının muhafaza edildiği görülmüştür: ana akım ve mevcut düzen karşıtllğı, göç karşıtlığı, refah milliyetçiliği ve Avrupa Birliği (AB) şüpheciliği. Ancak pandemi bağlamında bu unsurların ağırlığı değişmiş, ana akım ve mevcut düzen karşıtlığı, pandemi yönetimi konusuna uyarlanarak, ön planda yer almıştır. Refah milliyetçiliği, AB şüpheciliği ve İtalyan Lega partisi lideri Matteo Salvini dışındaki örneklerde göç, pandemiyle igili değerlendirmelerin odağında yer almamıştır.

Pandemiyi uzun soluklu ve çok boyutlu büyük bir kriz olarak değerlendiren PRSP liderleri, ana akım ve mevcut düzen karşıtlığı temelinde hükümetlerini hazırlıksız olmakla, strateji geliştirmemekle, vatandaşların sağlığını ve ekonomik güvenliğini koruyacak imkanları yeterli ve hızlı şekilde temin etmemekle eleştirmişlerdir. Ek olarak, yürütme organlarının acil durum önlemlerini, demokratik süreçleri dışlayarak kararlaştırdığına dikkat çekmişlerdir. Pandeminin ilk aylarında yapıcı eleştiriler ağırlıkta iken, özellikle Nisan 2020'den itibaren, eleştirilerin dozu ağırlaşmıştır. Ancak bu argümanlar, tutarsızdır. PRSP liderleri, bir taraftan önlemleri yetersiz bulurken, diğer taraftan hükümetleri aşırılıkla suçlamıştır. Bu noktada, PRSPler arasında bir yaklaşım farkı ortaya çıkmıştır. Avusturya ve Almanya PRSPleri pandeminin yayılmasına karşı uygulanan sokağa çıkma yasakları ve maske takma zorunluluğu gibi önlemleri temel haklara aykırı, totaliter uygulamalar olarak eleştirmiş ve Covid protestolarına üstü örtülü şekilde destek vermiştir. Fransa ve İtalya PRSPlerinin liderleri ise uzun müddet tam tersine, hükümetlerin koruyucu önlemlerde yetersiz kaldığını iddia etmiştir.

Popüler desteğe bakıldığında, 2020'nin ilk döneminde tüm ülkelerde hükümet desteğinin artarken, PRSP desteğinin azaldığı görülmüştür. Diğer bir deyişle, geçmiş krizlerin aksine, pandemi krizi, PRSPlerin yükselişini tersine çevirmiştir. Bu durum, literatürde güvenlik krizlerine ilişkin olarak tespit edilmiş "bayrak etrafında birleşme etkisi” (Murray, 2017) ile açıklanabilmektedir. Ancak bu etki, 2020'nin ikinci döneminde sona ermiş, dört ülkede sadece PRSPlerin değil, tüm ana partilerin popüler desteklerinde farklı yönlerde değişimler tespit edilmiştir. Bulgular, pandeminin geçmiş krizlerde görülen PRSP yükseliş eğiliminin son bulduğuna, ancak henüz ortak bir yönelim oluşmadığına işaret etmektedir. PRSPler arasında gerek söylem, gerekse popüler destek açısından tespit edilen farklılaşma, güncel krizin çok boyutlu olması ve geleceğe dair belirsizliğin sürmesi ile açıklanmıştır. 


\section{Sınırlılıklar}

Araştırmanın temel sınırlılı̆̆ı, zamana ilişkindir. Çalışma, bir yıllık bir süreci kapsamaktadır. Her ne kadar bu bir yıl içinde hükümet politikaları, siyasi parti pozisyonları ve kamusal tepkilerdeki değişikliklerin izlenebildiği gelişmeler yaşanmışsa da, pandeminin yayılması henüz önlenememiş, kesin tedavi bulunamamıştır. Pandemiyle başlayan ekonomik krizin etkileri, bütçe açılarılya ötelenmektedir. Bu durum, gerek hükümetlerin, gerekse PRSPlerin söylemlerinde ve popüler desteğinde yeni gelişmeleri olası kılmakta ve bulguların genellenmesine engel olmaktadır. Çalışmanın diğer kısıtı, söylemin pandemi ve kriz hakkındaki ifadeler üzerinden incelenmesinden kaynaklanmaktadır. Burada ortaya çıkan söylem önceliği değişimi, partilerin pandemi odağı dışında kalan kamusal ifadeleri değerlendirmeye katıldığında, geçerli olmayabilir.

\section{Öneriler (Teorik, Uygulama ve Sosyal)}

PRSPlerin pandemi öncesindeki yükselişi, Avrupa demokrasileri ve Avrupa entegrasyonunun kazanımlarını ciddi boyutta tehdit etmiştir. Krizlerin siyasi konumlanmada yarattığı kırılmayı geçmişte avantaja çevirmiş olan PRSPlerin yükselme eğilimi, pandeminin ilk yılında, bu partiler arasında oluşan farklılaşma ile sona ermiş görünmektedir. Ancak, İtalya ve Fransa gibi örneklerde PRSPler, halen iktidara gelebilecek denli güçlüdür. Bu gelişmeleri nedensellik bağlamında değerlendirebilmek için, pandemi ve sonrası dönemde, ülkelerin siyasi fırsat yapılarındaki değişimlere odaklanan ve ana akım partileri de içeren çalışmalara ihtiyaç vardır. Bu çalı̧̧manın bulguları, pandeminin geçmişte PRSPleri başarılı kılan söylem çerçevesini her ne kadar henüz tutarlılıktan yoksun da olsa, dönüştürebileceğine işaret etmektedir. Bu açıdan, PRSP söylemlerinin farklı alanlardaki değişimini izleyecek çalışmalar, literatüre büyük katkı sağlayacaktır.

\section{Özgün Değer}

Avrupa'daki PRSPlerin sürekli yükselişi ve bu yükselişin krizlerle ilişkisi, literatürde arz ve talep temelli yaklaşımlar kullanılarak derinlemesine analiz edilmiş, ortak bulgular elde edilmiştir (Albertazzi \& McDonnell, 2008; Kriesi \& Pappas, 2015; Poli, 2016; Mudde \& Rovira Kaltwasser, 2017; Ellinas, 2018). Ancak Covid-19 pandemisi, yakın geçmişte örneği olmayan, başta sağlık olmak üzere insan güvenliğinin birçok alanını kapsayan, çok boyutlu bir krize yol açmıştır. Dolayısıyla, geçmiş krizlere ilişkin tespitler, PRSPlerin güncel konumunu açılamada yetersiz kalmaktadır. Bu çalışma literatüre, bu yeni krizde Avrupa'daki PRSPlerin söylem ve popüler desteğindeki gelişmeleri ortaya çıkararak, yeni bulgular sağlamaktadır.

Araştırmacı Katkısı: Sevgi ÇİİNGİR (\%100). 